\title{
Existence of new rock unit of pink dolomite within the Midland succession of Balanch area, Darchula, Far-Western Nepal
}

\author{
*Ram Bahadur Sah1, Dilendra Raj Pathak², and Kabi Raj Paudyal1 \\ ${ }^{1}$ Central Department of Geology, Tribhuvan University, Kirtipur, Kathmandu, Nepal \\ ${ }^{2}$ Tri-Chandra Campus, Ghantaghar, Kathmandu, Nepal \\ *Corresponding author: paudyalkabi1976@gmail.com
}

\begin{abstract}
Geological setting and lithostratigraphy of Balanch area in the Darchula District, Far-western Nepal has been worked out with the aim to study the stratigraphy of the area. It has been found that the Bitule Dolomite developed in this area possibly represents the youngest rock unit of the Midland Group of the Nepal Lesser Himalaya. The Balanch area lies within the autochthonous zone of the Lesser Himalaya. The rock succession has been divided into six units: Bagadi Slate, Simar Talc Beds, Baril Dolomite, Tupkan Slate, Bitule Dolomite, and Balligad Sandstone. The Balligad Sandstone possibly belongs to the rock succession of Lower Tertiary whereas all other units belong to the Midland Group. From south to north, the area is characterized by the development of three tectonic zones. The southern zone is characterized by the development of oldest rock unit (Bagadi Slate) having NW to NE trend and dipping towards south and possibly thrusted over the middle zone. The middle zone is characterized by the development of the Simar Talc Beds, Baril Dolomite, and the Tupkan Slate, and also thrusted over rock succession of the northern zone, which is characterized by the development of the Bitule Dolomite and the Balligad Sandstone, the youngest rock units of the area. Geological setting and lithostratigraphy of Balanch area in the Darchula District, Far-western Nepal has been worked out with the aim to study the stratigraphy of the area. It has been found that the Bitule Dolomite developed in this area possibly represents the youngest rock unit of the Midland Group of the Nepal Lesser Himalaya. The Balanch area lies within the autochthonous zone of the Lesser Himalaya. The rock succession has been divided into six units: Bagadi Slate, Simar Talc Beds, Baril Dolomite, Tupkan Slate, Bitule Dolomite, and Balligad Sandstone. The Balligad Sandstone possibly belongs to the rock succession of Lower Tertiary whereas all other units belong to the Midland Group. From south to north, the area is characterized by the development of three tectonic zones. The southern zone is characterized by the development of oldest rock unit (Bagadi Slate) having NW to NE trend and dipping towards south and possibly thrusted over the middle zone. The middle zone is characterized by the development of the Simar Talc Beds, Baril Dolomite, and the Tupkan Slate, and also thrusted over rock succession of the northern zone, which is characterized by the development of the Bitule Dolomite and the Balligad Sandstone, the youngest rock units of the area.
\end{abstract}

Keywords: Bitule Dolomite, Midland Group, Balanch area, Far-Western Nepal

Paper Received: 31 Mar 2018

Paper Accepted: 29 May 2018

\section{INTRODUCTION}

The Balanch area lies within the Lesser Himalayan zone of Far-Western Nepal. Tectonically, it falls under autochthonous meta-sedimentary zone of the Lesser Himalaya that includes entire area of Chameliya Hydropower Project site. The metasedimentary succession of this area is mainly composed of lowgrade metamorphic rocks represented by slate, phyllite, crystalline limestone and dolomite, orthoquartzite and meta-sandstone. Department of Mines and Geology (DMG) (1987) has considered these rocks as a part of the Midland Group representing the Lakharpata Formation and the Galyang Formation and partly to the Surkhet Group ( Suntar Formation) of Lower Tertiary age. Similar stratigraphic positions have been also shown in the geological map of Nepal (Amatya and Jnawali, 1994). While conducting geological study of some parts of the adjacent area, Mahara and Sah (2007) have worked out the detailed lithostratigraphy of metasedimentary succession of the Baitadi area, Far-Western Nepal and they considered that the Julaghat Formation as the youngest rock unit. But, Pathak (2011) suggested that the Bitule Dolomite is considered as the youngest rock unit within the metasedimentary succession in the Balanch area of the Darchula District.

\section{GEOLOGICAL SETTING}

The Lesser Himalayan zone of Far-Western Nepal is characterized by the development of three thrust sheets named as Dadeldhura, Bajhang and Darchula thrust sheets, respectively which are composed of low-to high -grade metamorphic rocks more or less similar to the Bhimphedi Group (Stöcklin,1980; Amatya and Jnawali, 1994) in central Nepal (Fig. 1). The Balanch area lies within the autochthonous zone, along the Chameliya River in between Bajhang and Darchula thrust sheets which are the possible extension of Almora Thrust of the Kumoun Himalaya that developed in the west within the Indian 


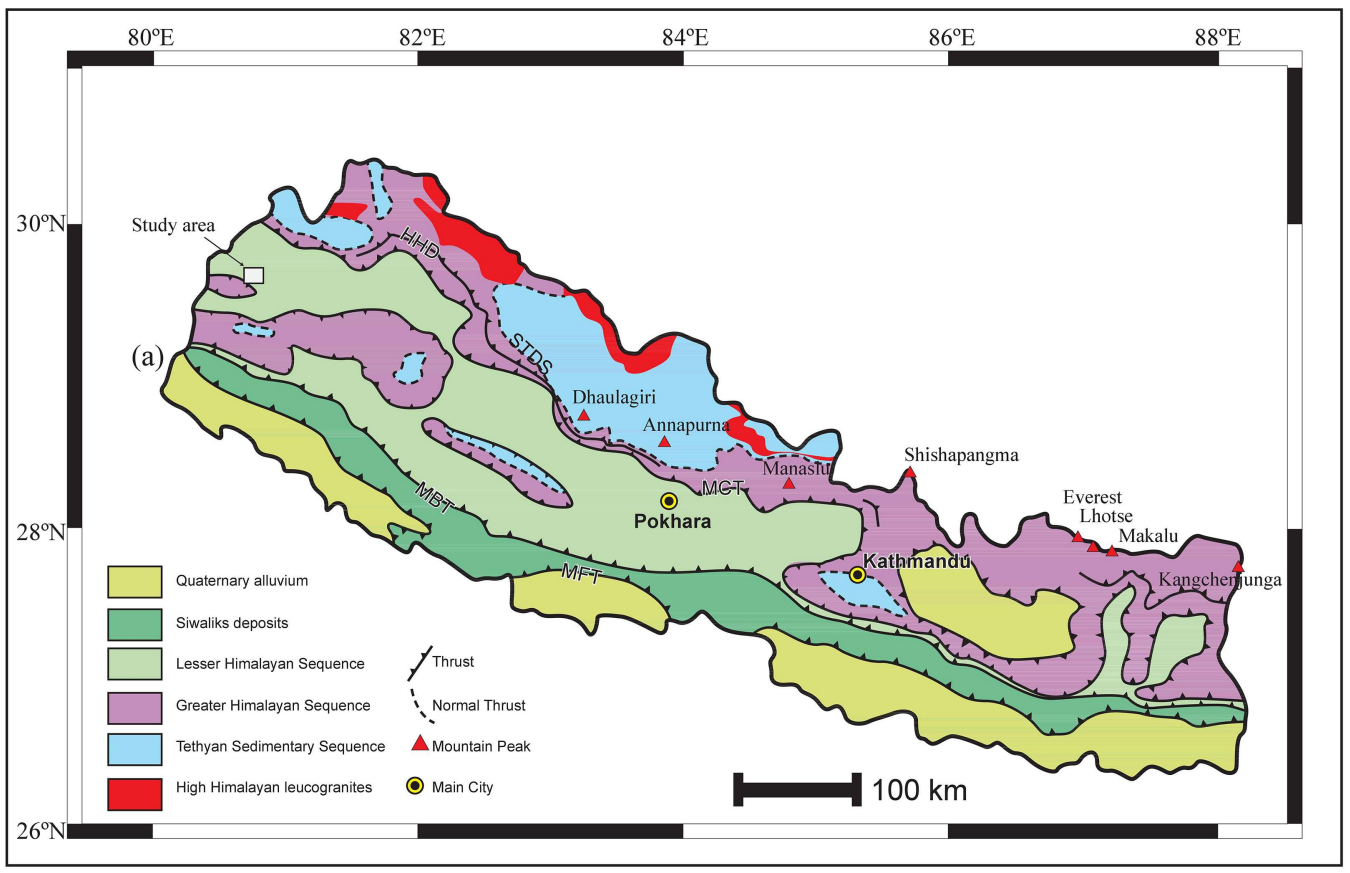

Fig. 1: Geological map of Nepal (Amatya and Jnawali, 1994) in scale 1:1000,000

Lesser Himalayan zone (Fuchs, 1980). The autochthonous succession in Balanch area is represented by the Precambrian rocks of the Nawakot Group and the rocks of Lower Tertiary ( $\sim$ Suntar Formation) as shown in geological map of Amatya and Jnawali (1994), Bashyal (1981), Kaphle and Khan (1993).

The Balanch village lies in the right bank of the Chameliya River at about $20 \mathrm{~km}$ NE of Gokule. In the geological map of DMG (1987) (Fig. 2), the rock succession of this area are shown as the Galyang Formation (Gl) and Lakharpata (Lk) Formation under the Midland Group and the Suntar Formation (Sn) as the Lower Tertiary under the Surkhet Group. Geological setting of Balanch area has been studied in detailed by Pathak (2011). The Balanch area is characterized by the development of three tectonic sub zones from south to north, respectively; they are Bagadi zone, Balanch zone, and Melbisa zone. The Bagadi zone is characterized by the development of slates having NW - NE trend and dipping towards south and possibly thrusted over the Balanch zone. This zone is characterized by the rock succession of talcosic dolomite striking E-W trend and dipping towards north and also having thrusted contact with the northern Melibisa zone. This zone is characterized by the rock succession of pink dolomite and greenish grey metasandstones having E-W trend and dipping towards south and underlain by the rock succession similar types as developed in the middle zone (Fig. 3).

\section{Lithostratigraphy of Balanch area}

The rock succession of Balanch area has been classified into six lithological units (Figs. 3 and 4) and compared with three groups as (i) Patan Group, (ii) Baitadi Group, and (iii) Lower Tertiary Group. In ascending order they are the Bagadi Slate, Simar Talc Beds, Baril Dolomite, Tupkan Slate, Bitule
Dolomite and the Balligad Sandstone (present study). The Bagadi Slate possibly belongs to the older succession of the Midland Group (Patan Group, Mahara and Sah, 2007, Fig. 4, right part). The rock succession comprising the Simar Talc Beds, Baril Dolomite, Tupan Slate and the Bitule Dolomiite constitute the rock succession equivalent to the Jhulaghat Formation, the upper most part of the Baitadi Group (Mahara and Sah, 2007). The Balligad Sandstone represents the rock of the Lower Tertiary. The Bitule Dolomite represents the new rock succession identified in this area. Lithological succession of each unit exposed in the study area is described briefly as follows:

\section{Bagadi Slate}

Based on the geological setting, the Bagadi Slate is the oldest rock unit developed in the Balanch area. It consists of black to light grey, reddish brown (when weathered), thinlybedded, well-foliated slate beds. The outcrop of this unit is well exposed at the bridge site over the Chameliya River near the Balanch School. The foliation planes are dipping towards south with dip amount ranging from $75^{\circ}$ to $85^{\circ}$ (Fig. 3). The thickness of the Bagadi Slate is more than $1000 \mathrm{~m}$, and locally it is mined for the purpose of house roofing as construction material. The Bagadi Slate has thrusted contact with underlying the Simar Talcosic Phyllite and Dolomite and so, it's stratigraphic position and its relation is not well understood in the Balanch area. It could be the older autochthonous succession of the Midland Group (Patan Group; Mahara and Sah, 2007) or a rock unit of allochthonous rocks of the Bajhang Klippe. This unit is developed within the southern tectonic zone of the area, which has been 


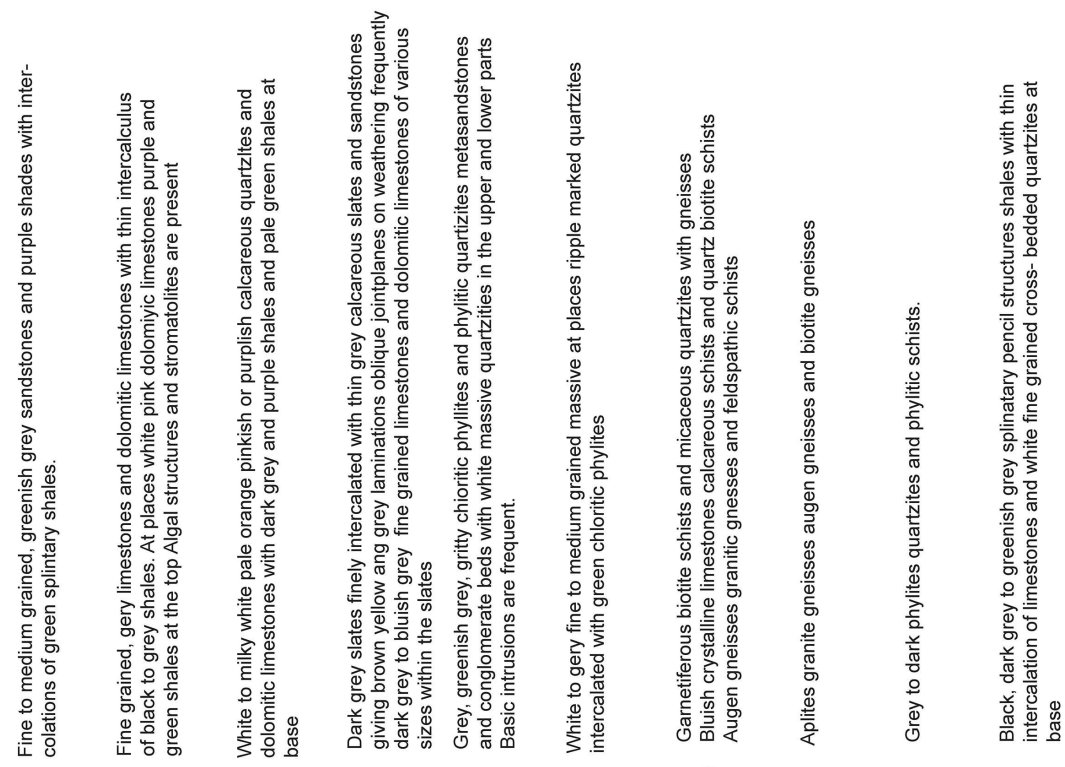

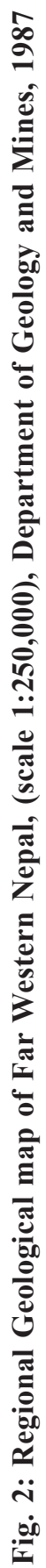

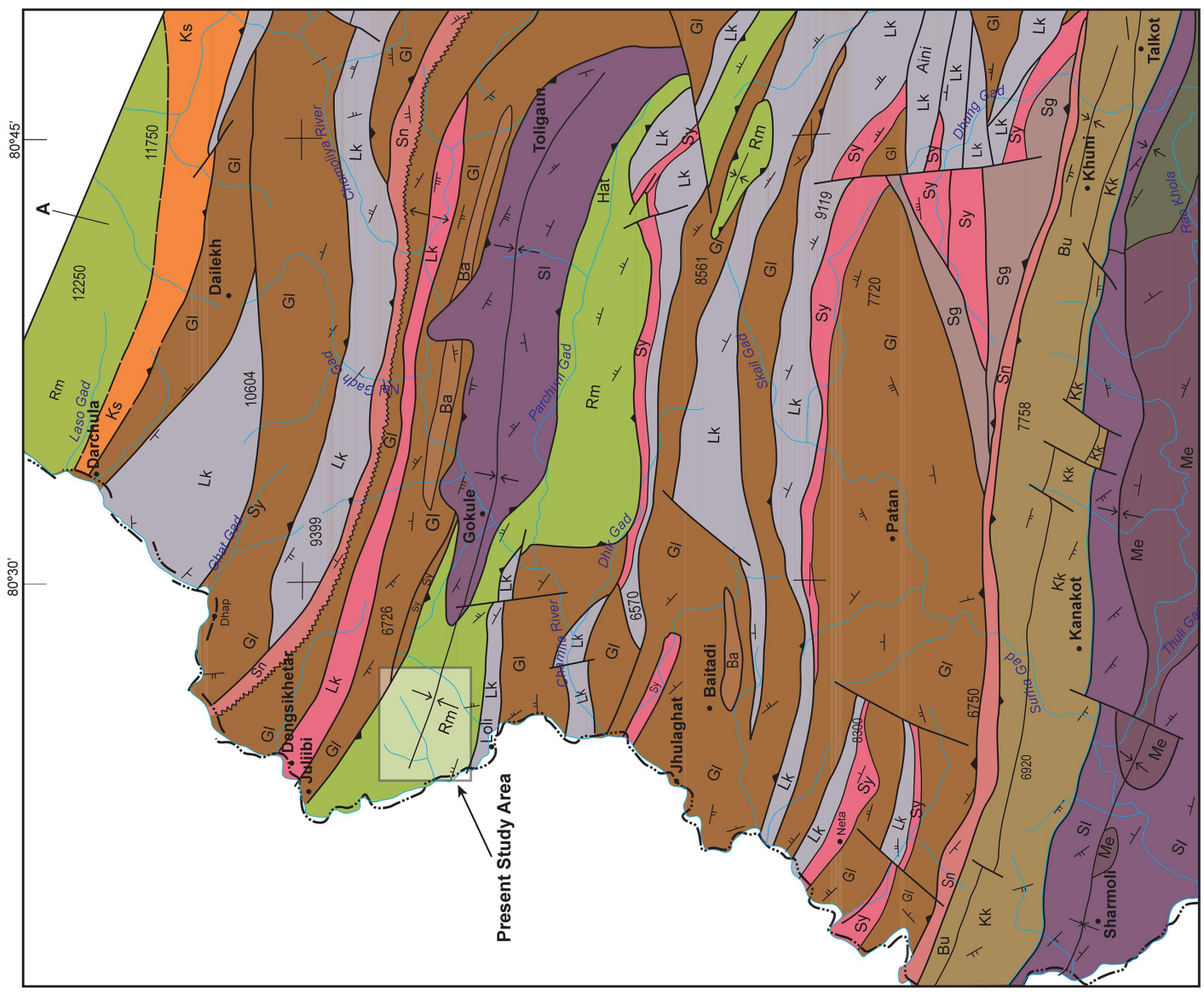



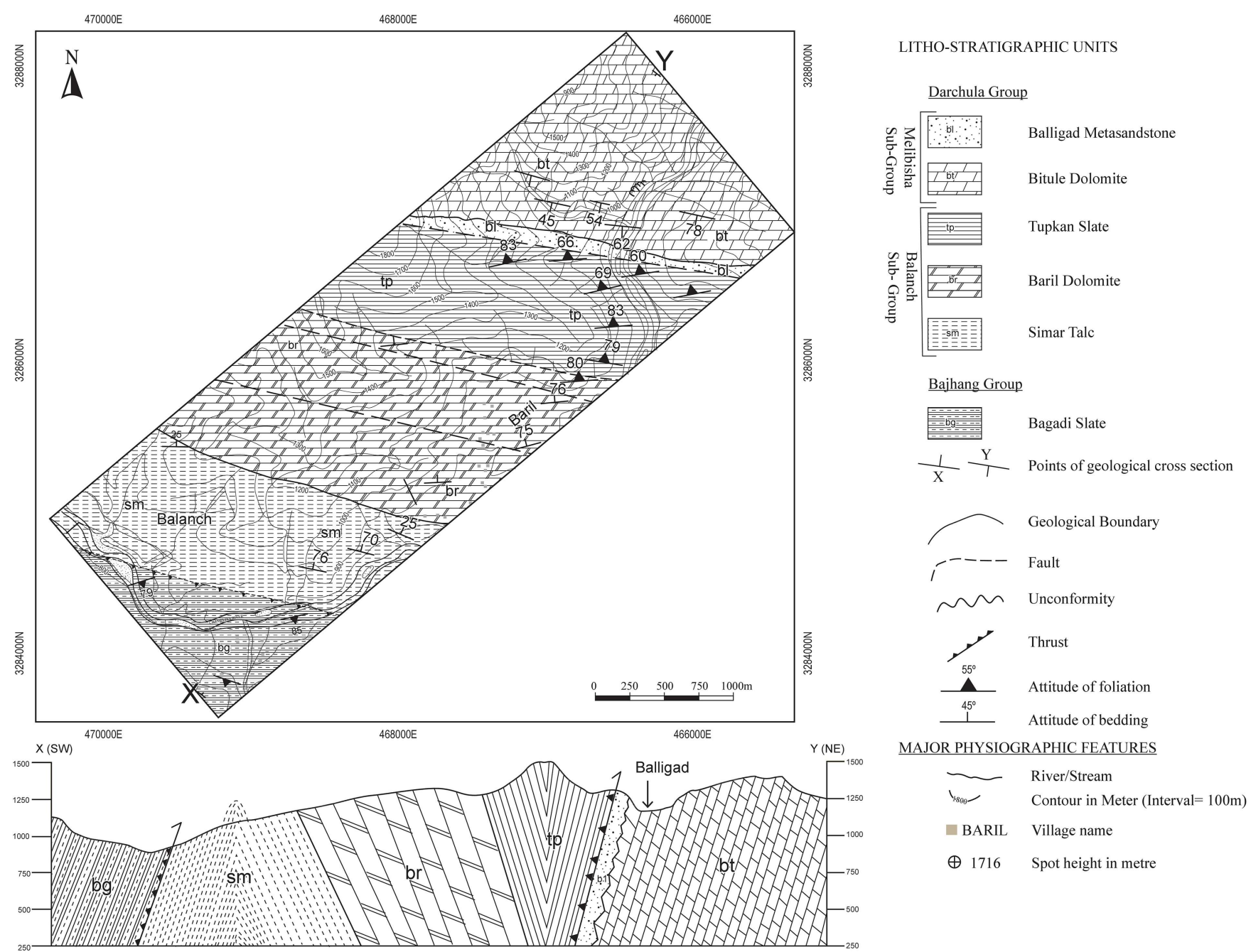

Fig. 3: Geological map (upper) and cross-section (lower) of the Balanch area of the Darchula District, Far Western Nepal (present work)

named as the Bagadi zone of the Bajhang Thrust Sheet.

\section{Simar Talc Beds}

This is the lowermost rock unit of the middle tectonic zone of the Balanch area (Fig. 4). It consists of dirty white to cream-colored, thinly-foliated and moderately-weathered phyllite, thin-to medium-bedded grey dolomite with some layers of calcareous slate. Talc beds are intercalated with dolomites and phyllites. Dolomite beds are highly fractured and weathered (Fig. 5). The lower part of this unit is cut by a thrust and its upper part gradually passes into the Baril Dolomites. The unit is more than $800 \mathrm{~m}$ thick.

\section{Baril Dolomite}

This unit consists dominantly of grey, medium-to thicklybedded, moderately-weathered, massive, stromatolitic dolomites with sub-ordinates of intercalation of phyllite in some parts (Fig. 4). Beds are well exposed along hill slopes and river banks around the Baril village. The succession gradually passes into the Tupkan Slate upwards. The thickness of this unit is about $1120 \mathrm{~m}$ and the attitude of bedding planes ranges from $76^{\circ} /$ $60^{\circ} \mathrm{NW}$ to $85^{\circ} / 76^{\circ} \mathrm{NW}$ similar to the underlying rock units. The succession is dissected by several local faults and shear zones. Fault-related features like slickensides and fault breccias are found in the area.

\section{Tupkan Slate}

It is the uppermost unit of the middle tectonic zone of the Balanch area (Fig. 4). Dominantly, this unit consists of black slate (Fig. 6) with rare intercalation of grey dolomite. The slate is thinly-foliated, slightly weathered, highly jointed and fractured. The rocks of the unit are well exposed around the Tupkan village and at the left as well as at the right banks of the Chameliya 


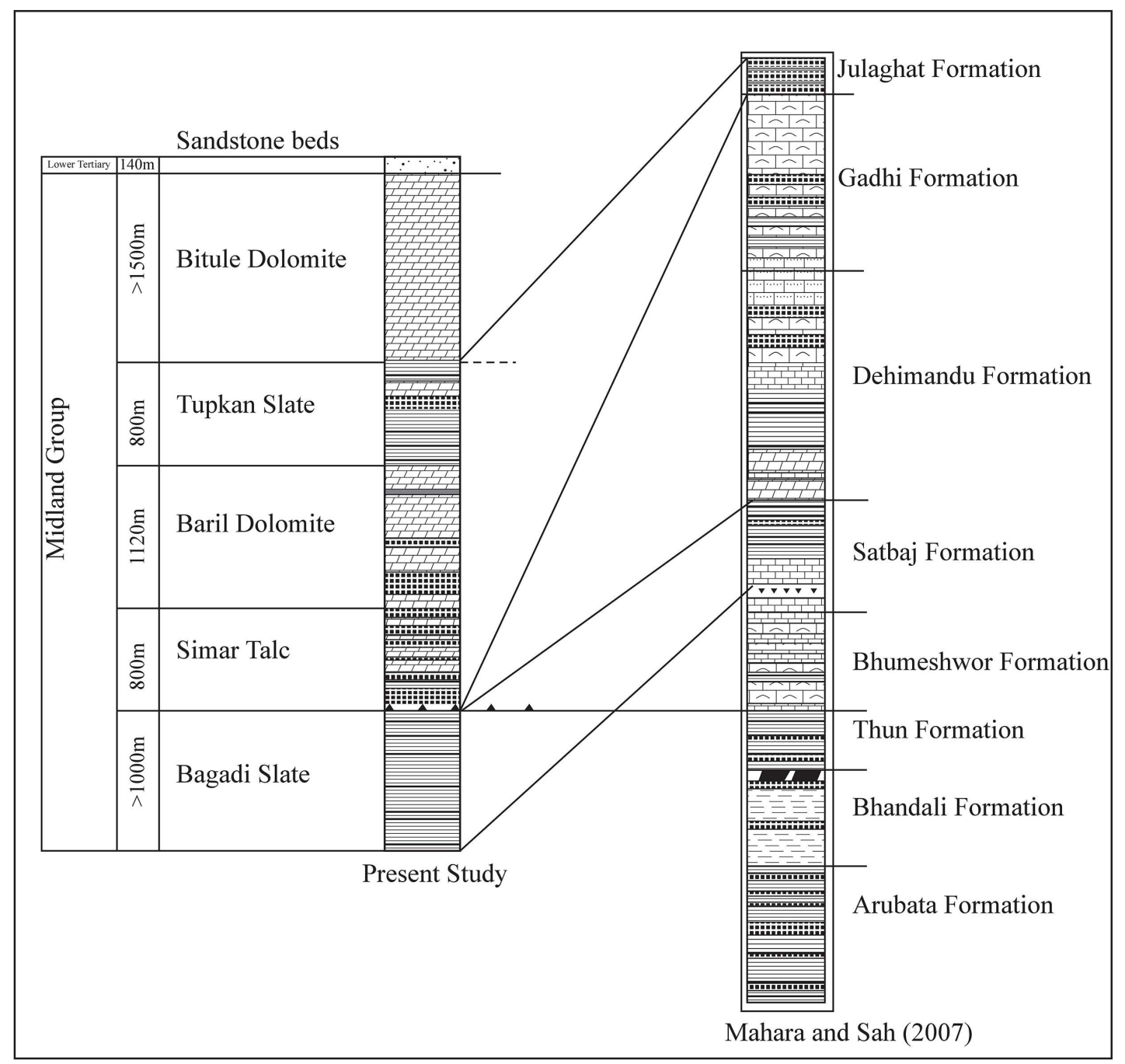

Fig. 4: Lithological succession of the Balanch area (left, present work) and comparison with lithological succession in Baitadi section (right, Mahara and Sah, 2007)

River. The upper part of this unit is cut by a thrust. The Tupkan Slate beds are thrusted over the Lower Tertiary succession of the Balligad rock unit. All three units of this middle zone seem to be comparable with the Julaghat Formation of the Baitadi area (Mahara and Sah, 2007).

\section{Bitule Dolomite}

The exposure of the Bitule Dolomite has been observed around the Bitule village, along Balligad and at the both banks of the Chameliya River around the head works of Chameliya hydro-electric power project. It consists of mainly pink, massive, highly-fractured (in certain parts), slightly-weathered continuous beds of dolomite and calcareous quartzite (Fig. 4). The thickness of individual bed ranges from $20 \mathrm{~cm}$ to $2.0 \mathrm{~m}$. At places columnar stromatolitic structure has been seen in the dolomite during the excavation of desanding basin during the Chameliya hydropower construction. The beds are dipping towards south and south- west opposite to that of middle zone. The attitude of beds ranges from $95^{\circ} / 52^{\circ} \mathrm{SW}$ to $107^{\circ} / 31^{\circ} \mathrm{SW}$. With transitional contact, the rock succession of the Bitule Dolomite and the Tupan Slate are developed in the Nala Bagad area on both banks of the Chameliya River. A very clear disconformity plane separates the Bitule Dolomite from the overlying Balligad Sandstones (Figs. 7 and 8). The thickness of the Bitule Dolomite is about $1500 \mathrm{~m}$ and it seems to be the youngest rock units developed within the meta- sedimentary succession of the Balanch area.

\section{Balligad Sandstone}

This unit consists of fine-to coarse-grained sandstone, pebbly-sandstone and some beds of ortho-quartzite (Fig. 4 and Fig. 9). The sandstone beds are light grey to greenish grey and show rusty color when weathered, medium-to thickly-bedded, moderately weathered, jointed and fractured. About $2 \mathrm{~m}$ thick basal conglomerate, i.e., pebbly sandstone bed has been observed 


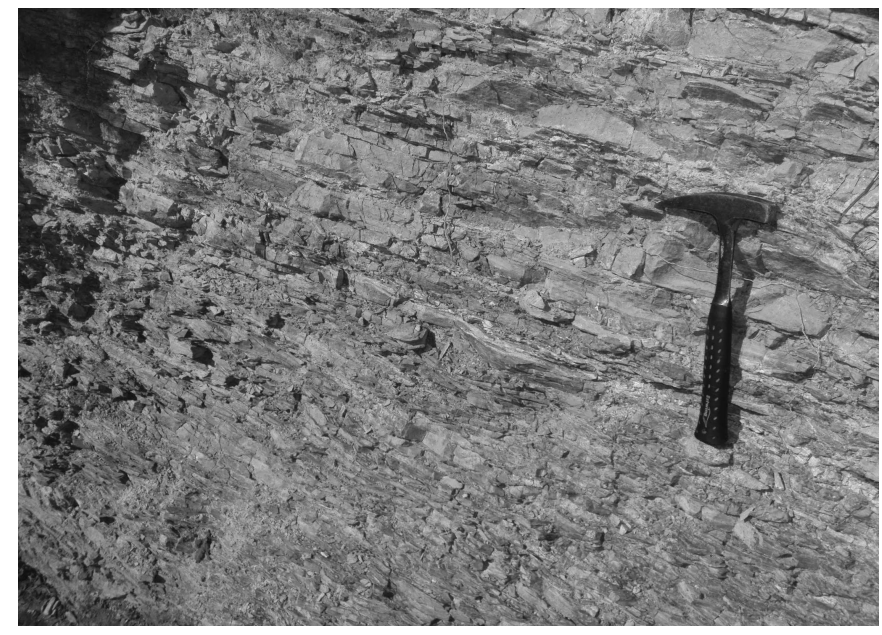

Fig. 5: Field photograph of fractured dolomite and intercalated phyllite of Simar Talc Beds at Balanch village

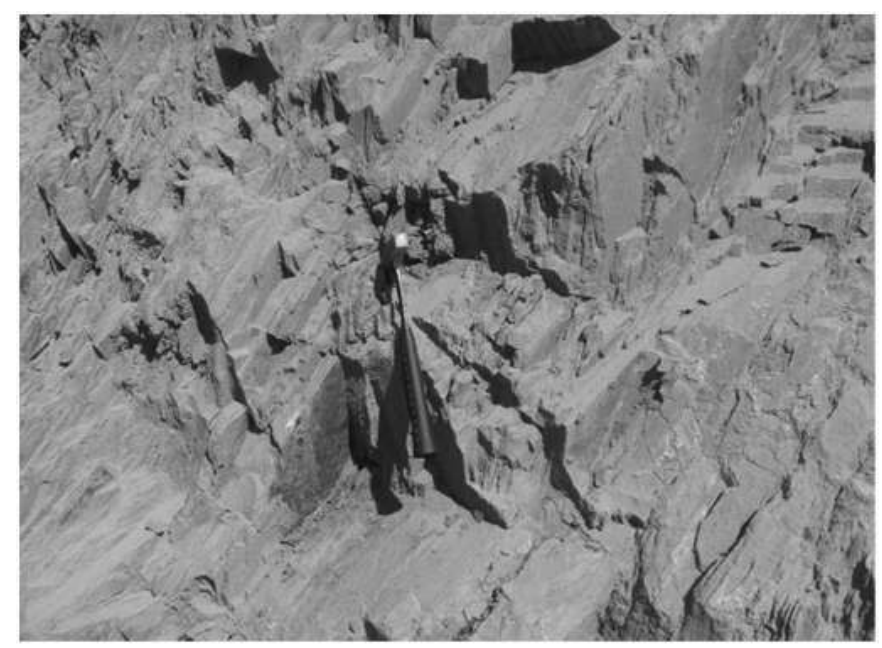

Fig. 6: Photographs of thinly-foliated and jointed black slate of the Tupkan Slate observed at the Tupkan village

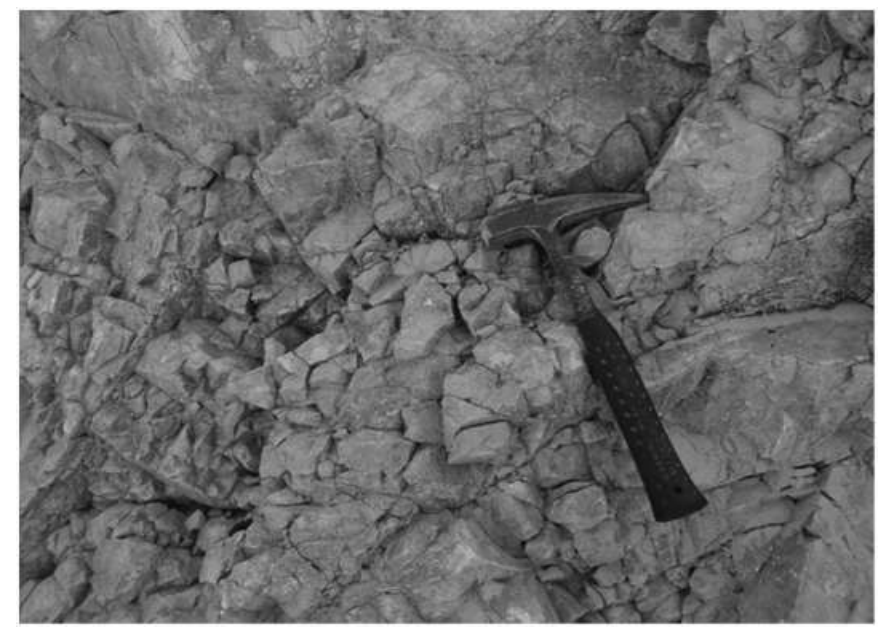

Fig. 7: Pink-Bitule Dolomite at the newly constructed damsite, on the right bank of the Chameliya River, Darchula

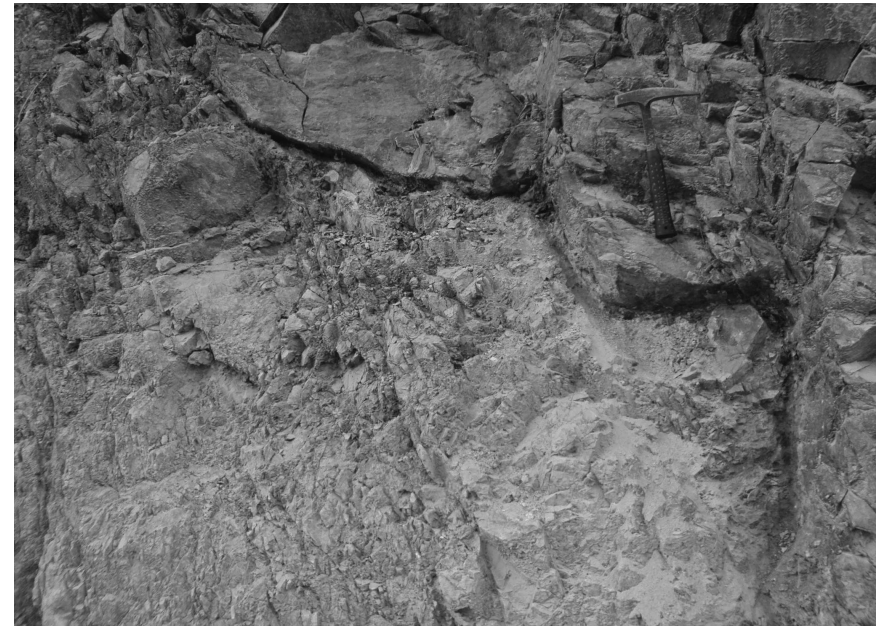

Fig. 8: Disconformity between the Bitule Dolomite and the Balligad Sandstone observed at the left bank of the Chameliya River near Bitule village

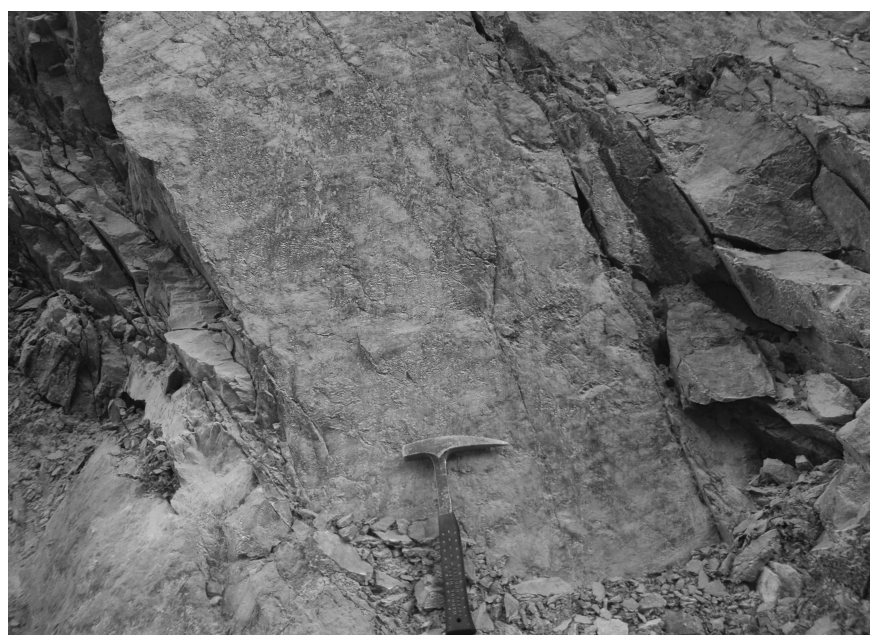

Fig. 9: Ourcrop view of the Balligad Sandstone observed at the left bank of the Chameliya River at Balligad area

at the contact with the Bitule Dolomite. In the conglomerate bed, pebbles of quartzite and slate are abundant ranging their sizes from $0.02 \mathrm{~m}$ to $0.10 \mathrm{~m}$. The bedding plane dips towards southwest and ranges from $62^{\circ}$ to $78^{\circ}$. The upper part of this unit is cut by a steep thrust and is overlain by the Tupkan Slate, an older rock unit. The unit is about $140 \mathrm{~m}$ thick in the Balanch area. Previous researchers have considered this sandstone unit as a rock succession of the Lower Tertiary as the Suntar Formation (DMG, 1987; Amatya and Jnawali, 1994; Kaphle and Khan, 1993).

\section{DISCUSSION AND CONCLUSIONS}

Several researchers have worked out the lithostratigraphy of metasedimentary succession of the Lesser Himalaya of Nepal (Stöcklin, 1980; Bashyal, 1981; Sakai, 1985; Paudel and Dhital, 1996; Dhital et al., 2002; Kaphle and Khan, 1993; Mahara and 
Sah, 2007; Paudyal and Paudel, 2011, 2013; Rai, 2011; Paudyal, 2014). It has been found that rock successions from the Kunchha Formation to Benighat Slate are well correlated (Sah, 2007; 2015). The rock succession younger than the Benighat Slate is much modified at different places and bears different nomenclatures. In central Nepal, it is represented by the Malekhu Limestone and Robang Phyllite (Stöcklin, 1980). In Western Nepal, at Syangja, it is represented by the Sorek Formation and the Dhanpure Limestone (Dhital et al., 2002); at Tansen, the Kerabari Formation (Sakai, 1985); in Far-Western Nepal at Baitadi constitutes the Dehimandu, Gadhi and Jhulaghat Formations (Mahara and Sah, 2007). Detailed stratigraphic works for the Precambrian metasedimentary rock succession of Far Western and Eastern Lesser Himalaya of Nepal is lacking and so it is difficult to correlate the upper part of the metasedimentary succession. It is possible that there exist facies changes during the deposition of the upper part of the succession resulting in various types of succession and some more new geological units above the Benighat Slate in western region. In comparison to eastern and central Nepal Himalayan regions, the upper metasedimentary succession seems to be more thick and complete in western and far-western Nepal. It seems that the Kerabari Formation in the Tansen area (Sakai, 1985), the Dhanpure Limestone of Syangja area (Dhital et al., 2002) and the Julaghat Formation of the Baitadi area (Mahara and Sah, 2007) represent the youngest metasedimentary rock unit in respective areas. Considering the stratigraphic position and geological setting, the Jhulaghat Formation of the Baitadi area seems to be younger than the Dhanpure Limestone of the Syangja area.

In further west from Baitadi, in the Balanch area of the Darchula District, the rock similar to the Jhulaghat Formation (Simar Talc Beds, Baril Dolomite and Tupkan Slate) is overlain by more than $500 \mathrm{~m}$ thick succession of pink dolomite, which is not found in any other succession so far. Therefore, possibly the pink Bitule Dolomite of the Balanch area in Darchula may be the youngest rock unit of the Precambrian metasedimentary rock succession of far western Nepal. Disconformable relation with the overlying Balligad Sandstones possibly belongs to the Lower Tertiary succession as mapped by the Kayastha (1992), Kaphle and Khan (1993); Amatya and Jnawali (1994).

\section{ACKNOWLEDGEMENT}

The authors would like to thank Prof. Dr. Lalu Prasad Paudel, Prof. Dr. Prakash Chandra Adhikary and Mr. Vinod Singh Chhetry for their fruitful discussions and suggestions while preparing the manuscript. The authors are also grateful to two anonymous reviewers for providing their valuable review comments for the improvement of the manuscript.

\section{REFERENCES}

Amatya, K. M. and Jnawali, B. M., 1994, Geological Map of
Nepal, Scale 1: 10,00,000.

Bashyal, R. P., 1981, Occurrences of Stromatolitic Phosphorites in Far Western Nepal, Baitadi and Bajhang districts, DMG unpublished report, p. 76.

Bashyal, R. P., 1981, Geology of Dhangarhi - Dadeldhura road section and its regional significance. Journal of Nepal Geological Society, v. 1, pp. 15-28.

Department of Mines and Geology (DMG), 1987, Geological map of Far Western Nepal, Scale 1:250,000, Department of Mines and Geology, Nepal.

Dhital, M. R., Thapa, P. B., and Ando, H., 2002, Geology of inner Lesser Himalaya between Kusma and Syangja in Western Nepal. Bulletin of Department of Geology, Tribhuvan University, Nepal, v. 9, pp. 1-60.

Fuchs, G., 1980, Geological- Tectonic Map of the Himalaya, Scale 1: 2,00,000.

Kaphle, K. P. and Khan, H. R, 1993, Geological Report on Reconnaissance and Preliminary follow up investigation of Gold, Uranium, and Base metals in Chameliya River and its catchment area in Baitadi and Darchula districts, Far Western Nepal. Department of Mines and Geology, unpublished report, 58p.

Kayastha, N. B., 1992, Stratigraphy of Lower Tertiary rocks of Nepal Himalaya. Journal of Nepal Geological Society, v. 8, pp. 21-30.

Mahara, A. S. and Sah, R. B., 2007, Lithostratigraphic Classification of Metasedimentary Succession of Baitadi Area, far western Nepal. Journal of Stratigraphic Association of Nepal (SAN), v. 6, pp. 1-10.

Pathak, D. R., 2011, Engineering Geological Study of Chameliya Hydroelectric project. M.Sc. Thesis, unpublished, Central Department of Geology, Tribhuvan University, Nepal, p. 86.

Paudel, L. P. and Dhital, M. R., 1996, Geology and structure of the area between Pokhara and Kusma Western Nepal Lesser Himalaya. Bulletin of Central Department of Geology, Tribhuvan University, Nepal, v. 5, pp. 47-60.

Paudyal, K. R., 2014, Geological and petrological evolution of the Lesser Himalaya in Mugling-Damauli area of central Nepal. Ph. D. Thesis submitted to Institute of Science and Technology, Tribhuvan University, Nepal, unpublished, $226 \mathrm{p}$.

Paudyal, K. R. and Paudel, L. P., 2011, Geological setting and lithostratigraphy of the Lesser Himalaya in the MuglingBanspani area, central Nepal. Journal of Nepal Geological Society, v. 42, pp. 51-64.

Paudyal, K. R. and Paudel, L. P., 2013, Geological study and root zone interpretation of the Kahun Klippe, Tanahun in central Nepal. Himalayan Geology, v. 34(2), pp. 93-106. 
Stratigraphic Association of Nepal (SAN), v. 6, pp. 11-20.

Rai, S. M., 2011, Lithostratigraphy of the Nawakot Complex (Lesser Himalayan sequence) from Malekhu area (southwest) to Syabrubensi area (north-east) along the Trishuli River, central Nepal Himalaya. Journal of Nepal Geological Society, v. 42, pp. 65-74.

Sah, R. B., 2007, Correlation of Precambrian metasedimentary rock-units of Nepal Lesser Himalaya. Journal of
Sah, R. B., 2015, Stratigraphy of Nepal. Special volume of Stratigraphic Association of Nepal (SAN), v. 10, 194 p.

Sakai, H., 1985, Geology of the Kaligandaki Supergroup of the Lesser Himalayas in Nepal. Memoire of Faculty of Science, Kyoto University, D (Geology), v. 25 (3), pp. 337-397.

Stöcklin, J., 1980, Geology of Nepal and its regional frame. Journal of Geological Society of London, v. 137, pp. 1-34. 